\title{
Postavy Němců v současné české próze
}

\author{
Petr Kučera (Plzeň)
}

\begin{abstract}
Abstrakt
Článek analyzuje postavy Němců v dilech současné české prózy, přičemž se zaměřje zejména na romány spisovatelek střední a mladší generace: Radky Denemarkové Penize od Hitlera (2006), Vyhnání Gerty Schnirch (2009) Kateřiny Tučkové a na román Němci (2012) Jakuby Katalpy jako pokus o nový pohled na problematiku života německy mluvících obyvatel od meziválečného období, přes vyhánění a následný odsun Němců z Československa až po problémy s restitucemi zkonfiskovaného majetku po roce 1989. Uvedené romány Ize interpretovat také jako skrytou polemiku s ideologicky a morálně akcentovanými přístupy k tématu.
\end{abstract}

\section{Klíčová slova}

současná česká próza; německy mluvící obyvatelé Československa; narativní struktura; jazyk a styl; Radka Denemarková; Kateřina Tučková; Jakuba Katalpa

\section{Abstract \\ The Characters of Germans in Contemporary Czech Prose}

The article analyzes the characters of the Germans in the works of contemporary Czech prose, focusing mainly on the novels of middle and younger writers: Radka Denemarková Money from Hitler (2006), The Expulsion of Gerta Schnirch (2009) by Katerina Tučková and the novel The Germans (2012) by Jakuba Katalpa. as an attempt at a new perspective on the life of German-speaking people from the interwar period, through the expulsion and subsequent expulsion of Germans from Czechoslovakia, to problems with the confiscation of confiscated property after 1989. These novels can also be interpreted as a hidden controversy with ideologically and morally accented approaches.

\section{Key words}

contemporary Czech prose; German-speaking inhabitants of Czechoslovakia; narrative structure; language and style; Radka Denemarková; Kateřina Tučková; Jakuba Katalpa 
Problematika literárních obrazů příslušníků cizího etnika je předmětem literárně orientované komparativní imagologie, jejíž rozkročení mezi literární komparatistiku, etnologii, sociální psychologii, sociologii, politologii a další disciplíny generuje řadu zajímavých otázek, na které se však velmi obtížně hledají uspokojivé odpovědi. Svědčí o tom mj. již poměrně dlouhá tradice sporů o pojetí literární komparatistiky, v nichž proti sobě stojí zastánci filologického a estetického jádra literární komparatistiky na straně jedné a iniciátoři exkurzů do mimoliterárních oblastí na straně druhé. ${ }^{1}$ Podíl literárních textů na vytváření a šíření národních stereotypů jistě nelze srovnávat s vlivem tradičních a zejména nových médií, což však neznamená, že je zanedbatelný. Za pozornost jistě stojí i možnosti některých žánrů umělecké literatury hlouběji zkoumat problematiku představ o tzv. druhých (národech, menšinách apod.). Je to v prvé řadě žánr románu, který je pozoruhodným zpo̊sobem „vypreparován“ k prozkoumávání rozmanitých zákoutí lidské psychiky a jejích proměn v důsledku krizových společenských událostí.

V případě zemí Koruny české je vztah českého a německého živlu natolik komplikovaný, že základní imagologické kategorie (autoimago a heteroimago) vyžadují doplnění o jemnější nástroje. Osm století soužití Čechů, Němců a Židů vytvořilo složité konstelace, v nichž kategorie jako „vlastní“, „cizí“, „stejné“, „jiné“, „vlast“, „cizina“, „blízkost“, „dálava“ nebo „domov“ získávají nezř́ídka překvapivé významy.

Václav Maidl shrnuje v závěru své studie ${ }^{2}$ převažující tendenci v novodobé české literatuře: „[...] německé postavy a německé prostředi jsou v ni až na ř́dké výjimky zobrazeny negativně. Ze staršich fázi svého vývoje přejimá pojeti Němce jako vetřelce (nikoli už jako konkurenta) a protivnika. Př́kladnost Němců na poli kulturním (Jungmann) je rychle zapomenuta a obraz protivnika se se vzrůstajicím [...] národnostním bojem jevi čim dál negativněji: Němci jsou pojimáni jako hubitelé Slovanů a stálé ohrožení českého národa. Národnostni antagonismus v literatuř začíná narůstat od 40. let 19. stoleti a kulminuje v jeho posledni třetině a na přelomu 19. a 20. století. Po vzniku samostatného Československa [...] můžeme naopak v náznaku zachytit pokusy o porozuměni „druhé straně“ (Durych, Majerová). Rozbiti republiky a následných šest let okupace vyhrotily vztahy opět antagonisticky a ovlivnily tak tím i poválečnou literaturu [...].“3

Po roce 1989 dochází v české publicistice a próze k více či méně mechanickému morálnímu přehodnocování postav sudetských Němců. Z bývalých stoupenců nacismu se stávají kladné postavy bezbranných obětí českého násilí. Strukturovanější pohled se spíše než v české próze objevil v pracích historiků, sociologů i publicistů. ${ }^{4}$

1 Připomeňme zde alespoň polemiku zakladatelské osobnosti současné komparativní imagologie Huga Dyserincka (srv. studii Zum Problem der 'images' und 'mirages' und ihrer Untersuchung im Rahmen der Vergleichenden Literaturwissenschft. In: Arcadia 1, 1966, s. 107-120) s myšlenkami, které vyslovil zastánce nerozvolněné literární komparatistiky René Wellek na II. kongresu ICLA The Crisis of Comparative Literature. In: Proceedings of the second congress of the International Comparative Literature Association, Chapel Hill 1958. Chapel Hill, 1959, s. 149-159.

2 MAIDL, Václav: Obraz německy mluvicich postav a německého prostředí v české literatuře 19. a 20. století. In: KŘEN, Jan - BROKLOVÁ, Eva (eds.): Obraz Němců, Rakouska a Německa v české společnosti 19. a 20. století. Praha: Karolinum, 1998, s. 281-302.

3 Tamtéž, s. 299.

4 Nejobsáhlejší publikací přinášející nová fakta a nové pohledy je monografie STANĚK, Tomáš: Odsun Němců z Československa 1945-1947. Praha: Academia, 1991; v širším historickém a evropském kontextu srov. 
Stereotyp o spravedlivém odsunu nacisticky smýšlejících Němců z Československa narušují v devadesátých letech 20. století informace o odsunu nejen aktivních nacistů, ale i lidí politicky neangažovaných, části německých antifašistů nebo dokonce obětí hitlerovského režimu.

Z československých občanů byli nejhưře postiženi německy mluvící Židé, kteří se na konci války vrátili z nacistických koncentračních a vyhlazovacích táborů, nemohli se domoci navrácení svých zabraných obydlí a jako údajní Němci byli zařazováni do vysídlovacích transportů. V Československu naopak zůstali aktivní nacisté, kteří byli jako odborníci nenahraditelní v průmyslu nebo byli využitelní v tajných službách.

Opuštěnou krajinou Sudet a stopami jejího nedávného osídlení se zabývaly mj. prózy Vladimíra Körnera (Podzimní novely), Václava Vokolka (Pátým pádem) nebo Jaroslava Durycha (Boží duha). Osudy původních obyvatel však v nich byly zobrazovány převážně zprostředkovaně pomocí pozůstatků jejich materiální kultury v nejširším smyslu.

Tradiční stereotypy o Němcích ${ }^{5}$ přežívaly v silné podobě i v devadesátých letech 20. století. Odvahu věnovat se intenzivně tabuizovaným tématům česko-německých vztahů nalezly české prozaičky střední a mladé generace. Výsledkem jejich zaujetí nezpracovanými traumaty nedávné historie jsou romány, které představují novou kvalitu nejen v intelektuálním přístupu k tématu, ale zejména v originalitě uměleckého ztvárnění.

Radka Denemarková (1968) byla k zájmu o bílá místa v dějinách česko-německých vztahů motivována nejen odbornou erudicí (vystudovala bohemistiku a germanistiku, působila na univerzitě a v Ústavu pro českou literaturu Akademie věd ČR) a překladatelskou praxí (překlady německých historických studií, divadelních her a próz), ale také znepokojením ze zamrzlé české debaty o vyrovnávání se s minulostí. Po novele A já pořád kdo to tluče (2005) vydala v brněnském nakladatelství Host román Peníze od Hitlera (s podtitulem Letní mozaika).

Hrdinka románu Gita Lauschmannová ztělesňuje krajnosti tragického osudu přeživších šoa. Po návratu z nacistického koncentračního tábora, kde byla její rodina zavražděna, nenalézá v rodné vsi ani náznak vlídného přijetí. Majetek židovské rodiny Lauschmannů byl zabaven, protože rodina byla označena za německou (členové rodiny mluvili doma často německy, účetní knihy z rodinného lihovaru a velkostatku byly vedeny v němčině).

Obyvatelé Puklic vnímají Gitu jako nežádoucí, nebot’ by mohla zproblematizovat vlastnictví majetku, kterého se po válce zmocnili. Gita tak i po válce opět málem přijde o život, tentokrát v důsledku týrání bývalými sousedy - záchrany v podobě pomoci při útěku se nečekaně dočká od těhotné ženy, která obývá její rodný dům.

Po letech Gita obdrží od německé vlády finanční odškodnění za utrpení způsobené nacistickým režimem a rozhodne se vrátit do Puklic, aby očistila otcovu památku vytvořením

monografii SEIBT, Ferdinand: Německo a Češi. Dějiny jednoho sousedstvi uprostřed Evropy. Praha: Academia, 1996.

5 Srov. např. studii RATAJ, Jan: Obraz Němce a Německa v protektorátni společnosti a československém odboji. In: KŘEN, Jan - BROKLOVÁ, Eva (eds.): Obraz Němců, Rakouska a Německa v české společnosti 19. a 20. století. Praha: Karolinum, 1998, s. 207-235; jakož i studii SCHALLNER, Dieter: Obraz Němců a Německa v letech 1945 až 1947. Vznik soudobého českého stereotypu Němce a Německa. In: Tamtéž, s. 236-252. 
pomníku a zřízením muzea. Potomci bývalých osídlovatelů vylidněných Puklic se obávají oprávněnosti Gitiných restitučních nároků a snaží se je právními kličkami zpochybnit (např. poukazy na nevěrohodnost žadatelky, která se - po prožitých hrůzách - stala psychiatrickou pacientkou).

Zastání se Gitě dostane od lékaře Denise, syna Gitiny zachránkyně, který se díky svému neutrálnímu postavení (pochází z Puklic, ale v obci již dlouhou řadu let nežije) stává prostředníkem znesvářených stran sporu. Od své umírající matky se v závěru románu dozvídá pravdu o hrůzných poválečných událostech v Puklicích.

Postavy Němcủ v románu reprezentují německy mluvící (a německými nacisty zavraždění) členové židovské rodiny Lauschmannů, která napomohla meziválečnému rozkvětu obce. Gita Lauschmannová se v důsledku totalitních režimů stává tragickou postavou s nejednoznačnou identitou - necítí se být Židovkou (její židovství jí silně připomněli až nacisté), ale ani Němkou.

Základním uměleckým prostř̌edkem románu je kontrast v rovině jazykově stylistické, méně pak v plánu tematicko-motivickém. Před individuální charakteristikou postav jazykem promluv či vnitřních monologů upřednostňuje autorka skupinovou charakteristiku na ose spisovnost - nespisovnost: vzdělané postavy (lékařka Gita, lékař Denis či studentka práv Barbora) tíhnou ke spisovnosti, vesničané kontrastně $\mathrm{k}$ obecné češtině s nářečními rysy a množstvím germanismů, ale také archaismů či naopak neologismů.

Kontrast kultivované mluvy vzdělaných lidí a germanismy prostoupeného jazyka českých nacionalistů odkazuje k pokrytectví moralizujících xenofobů, zprostředkovaně také ke kulturně historické provázanosti obou zemských jazyků na našem území. Gita je obviňována z kolektivně uplatňované viny německého národa na základě pouhého použivání německého jazyka: „Žádnej haus už nejni tvưj. [...] Vina tvý familie je nezuratná. Podstatná byla a je vobcovací rěč. A ausgerechnet u vás se [...] šprechtilo ostošest. "6

Pro výrazně emocionální vyznění slov, která vyvolávají vzpomínky na zakoušené pocity smutku, trapnosti, ubohosti a bolesti, má velký význam autorčin verbonominální styl. Důraz na emocionálně zabarvená a neobvyklá adjektiva a dějová slovesa v partu vypravěče a ve vnitřních monolozích hrdinky souvisí s autorskou strategií přenášet pozornost od pozorování a vnímání k prožívání. Nemalou roli v celkové kompozici textu sehrávají také aluze na lidovou slovesnost, jejíž etický náboj vyniká v kontrastu se zvráceným myšlením a jednáním válečných a poválečných násilníků a vrahů.

Literární kritika upozorňuje na některé problematické rysy jazykového stylu próz Radky Denemarkové. Jiří Trávníček píše v souvislosti s autorčinou prvotinou o „stylistickém narcismu“, nadbytek adjektiv sloužících k rychlé charakterizaci považuje za „dekoratérské tahy“.7 Marek Vajchr vytýká románu Peníze od Hitlera jazyk, který je „vypiplaně patetizujíic““ ${ }^{8}$ Martin Pekárek považuje metafory Radky Denemarkové za „křečovité“.${ }^{9} \mathrm{O}$ rozporuplném přijetí románu v české společnosti svědčí také čtenářské reakce v diskusních fórech na sociálních

6 DENEMARKOVÁ, Radka: Penize od Hitlera (Letni mozaika). Brno: Host, 2006, s. 34.

7 TRÁVNÍČEK, Jiří: V této knize se toho sešlo nějak moc. Host 21, 2005, č. 7, s. 11-12.

8 VAJCHR, Marek: Dobrosrdečný mazák a divý borec. Revolver revue, 2007, č. 68, s. 225-230.

9 PEKÁREK, Martin: Jednou se stanu spisovatelkou. Protimluv 5, 2006, č. 3, s. 35-36. 
sítích, v nichž se střetává obdiv k autorčině jazykové virtuozitě s poznámkami o narušování čtenářského zážitku nadbytečnou jazykovou hrou.

Čtenářskou pozornost na sebe strhává hypertrofovaná imaginativnost textu, jejíž alogičnost - připomínající v lecčems surrealismus - však zároveň symbolizuje posuny Gitiny psychiky, zřejmě trvale narušené válečnými a poválečnými traumaty. Čtenářský diskomfort je tak do jisté míry funkční, nebot souzní s celkovou autorskou strategií díla zprostředkovat literárním textem obtížně sdělitelné mentální obsahy.

Autorka tíhne k technice připomínající obrazy surrealistických malírư - např́ílad obraz sugerující představu rozhlížení se po rodném kraji, jehož současnost je náhle cizí a nepochopitelná, zvolila autorka pro zachycení kritické životní situace, kdy je Gita po návratu z koncentračního tábora přivázána českými „vlastenci“ ve stodole, aby zde zemřela hlady: „Kebule buji do výšky poloztrouchnivělého ořechu. Jeho stín dokáže drapnout ještě zápraži naši vily se zábradlim. Kebule vzrůstá $k$ tušeným oblakům, aby protáhlýma, šikmýma očima obhlédla ztmavlý kraj. Do kterého jsem vrostla a který mě odmítá. Krk se protahuje a úží. Obrovitý maják vylétne vzhưru na tenkém provázku. Makovice zacloni měsíc a hvězdy, svět potemni ještě víc. Všechny tváre tu znám. A nikomu nerozumím."10

Obraz Gity Lauschmannové získává v metaforách uvedeného typu méně jednoznačné kontury, postava je stále více propojována s přírodními ději, je vyvazována ze sféry jasných idejí, názorů, postojů - ze své beznadějné pozice „inter“ usiluje po celou dobu o dialog s prostředím, které se vzdaluje lidskosti. Slovenský básník Miroslav Válek definoval ve sbírce Prítažlivosṫ (1961) metaforicky domov jako „ruky, na ktorých smieš plakat" - domov v tomto smyslu pro Gitu nenávratně mizí.

Složité psychické pochody v mysli hlavní postavy podtrhuje nejen rozmanitě utvářený rytmus prózy, ale i eufonie ve stylu dětských ř́ikanek a lidové poezie, která sugeruje návraty do kraje dětství a vnímání neopouštějící dětskou představivost. Vysoce kreativní je autorka také ve využívání symboliky barev - u hlavní postavy zejména žluté v nadčasových významech slunce, světla i ve významech dobově aktuálních. Úsilí o fotografickou či filmovou imaginativnost se projevuje ve hře se světelnými paprsky, šerosvitem a hrou stínů. Nikoli náhodou je román doprovázen devíti černobílými fotografiemi Evy Fukové (včetně titulní fotografie parku bez lidí se zahradními židlemi a stolem s opuštěnými šálky).

Také vůně dotvářejí jedinečnou atmosféru krajiny a spolu s teplotními kontrasty odkazují k hypersenzitivitě hrdinčina podvojného vnímání jevů. Nejde přitom o náladové ilustrace, ale o podstatné události Gitina bohatého vnitřního života, čemuž odpovídá i dramaticky vystupňovaná větná skladba osamostatňující jednotlivé vedlejší věty i větné členy: „Tajuplné vưně a směs erotického jiskření, kdy čas stál, jen se nehybně vlnil nad obzorem. Nosem a všemi póry těla se derou pachy posečené trávy. Těžké, uspávavé vưně lučnich květin. Pronikaji do morku kostí, rozněcuji asociace vzpominek, zaklesávaji se do sebe jako těžká oka

10 DENEMARKOVÁ, Radka: Penize od Hitlera (Letni mozaika). Brno: Host, 2006, s. 51.

11 VÁLEK, Miroslav: Domov sú ruky, na ktorých smieš plakat'. In: VÁLEK, Miroslav: Básnické dielo. Bratislava: Kalligram - Ústav slovenskej literatúry SAV, 2005, s. 96-97. 
utahujicich se řetězů. Kterými je pani Lauschmannová obmotána jednou provždy. Chladivý kov v tom horku zamrazi."12

V každé významové vrstvě díla je patrné autorčino úsilí o maximální smyslovou názornost. Proces ztráty domova a s ním spojené změny ve vnímání kategorií vlastního a cizího, stejného a jiného, blízkosti a dálavy je soustavně vyvazován z neproblematických hodnotových souřadnic a stereotypů chování. Na rozdíl od „pouhé“ ztráty domova je tento proces mnohonásobně umocněn terorem totalitních režimů, v nichž se na Gitině rodině i jí samé dopustili nejhorších násilností nejen reprezentanti moci, ale i tzv. obyčejní lidé.

Nejde však „pouze“ o fyzické násilí a s ním spojená psychická traumata, která se v případě hlavní hrdinky ukazují jako celoživotní. Psychotické stavy (v rovině individuální i nadindividuální) prohlubuje převrácení kategorie cizího - legalizovaný vpád vetřelců (novousedlíků) týrajících německé starousedlíky i židovské navrátilce z koncentračních táborů jako provinilé cizince.

Návratem hlavní hrdinky do rodné vsi v roce 2005 obohatila autorka významové dění díla o fenomén nové cizosti, která ve vzpomínkách a následných reflexích dává zesíleně tušit, že Gitino duševní stáří započalo dávno před stářím fyzickým - v době, kdy se začala odcizovat sama sobě, „kde jsem v baráku svlikla dětskou kưži a na hrbu si pritáhla kůži zatěžkanou plivanci ponízeni a studu“. ${ }^{13}$

Gita Lauschmannová se po sérii mimořádně traumatizujících životních peripetií dostává do stavu, o němž - v souvislosti se svými vlastními prodělanými traumaty (transplantací srdce a rakovinou) - píše francouzský filosof Jean-Luc Nancy: „Jsem snad sám pro sebe jakýmsi opojením? Nepochybně. Nèkdy je to opojeni lehké, vzdušné, jindy zase závratné a těžké, avšak stále mne zdržuje od prosté jistoty, že bych byl „sám sebou“. Pocítit „jástvi“ je nekonečně vzdáleno za mnou i prede mnou, to je dojem, uvědoměni, smysl, který by žádný význam a žádná identita nikdy nemohly zahladit." 14

V románu Kateřiny Tučkové Vyhnání Grety Schnirch ${ }^{15}$ se česká čtenářská veřejnost setkává s rozměrným literárním obrazem divokého vyhánění Němců z Brna. Na svátek Božího těla, v noci z 30. na 31. 5. 1945 vyhnali česky mluvící Brňané tisíce německy mluvících brněnských žen, dětí a starců (muži byli uvězněni) z rodného města. Při nelegálním aktu bylo na cestě k Pohořelicím mnoho vyháněných zastřeleno nebo ubito, další zemřeli v důsledku vyčerpání nebo epidemií, stovky zahynuli ve zbědovaném stavu na rakouském území. Brněnský pochod smrti patřil po celou druhou polovinu 20. století k nejvíce tabuizovaným událostem poválečných československých dějin.

Postava Gerty Schnirch ztělesňuje řadu protikladů a paradoxů česko-německého soužití. Pochází ze střední vrstvy, její rodina je národnostně smíšená, což v době meziválečného Československa nevyvolávalo vážné konflikty. Německý otec s násilnickými sklony - znásilnil Gertu, která se neúspěšně pokusila o potrat - se ve vypjaté protektorátní

12 DENEMARKOVÁ, Radka: Penize od Hitlera (Letni mozaika). Brno: Host, 2006, s. 82-83.

13 Tamtéž, s. 67.

14 NANCY, Jean-Luc: Vetřelec. Filosofický časopis 59, 2011, č. 1, s. 47-59.

15 TUČKOVÁ, Kateřina: Vyhnáni Gerty Schnirch. Brno: Host, 2009. 
atmosféře přidá na stranu nacistů a postupně utrápí svou českou manželku. Svou českou matku Gerta upř́ímně milovala, avšak vůči otci - i vůči bratrovi Fridrichovi, který napodobuje otce a koncem války narukuje na východní frontu - pocituje rostoucí nenávist.

Již první poválečné dny pocítila Gerta silný strach z budoucnosti:

„Dvanáctého května stála na okraji davu. Stála na rohu pod michalským kostelem, pod sochami, které na ni z rampy ochozu shližely, svatý Pavel soucitně, s hlavou sklonènou a s knihou pevně pritisknutou $k$ hrudi. [...]

Gerta měla strach. Obrovský, sidlil ji hluboko v uvnitř hrudi, rozlezlý jak pavouk osmi nohama do všech částí jejîho těla. Těžké, masité, široké tělo hmyzu jí zatěžkávalo hrud’, na kterou z vnějšku tiskla Barboru, jejiž hlavička poklimbávala dopředu a dozadu, stále dokola.

Vědèla, že porušuje vyhlášku a že za jeji nedodrženi vyhlásili trest smrti. [...] Co by asi udělali s ni, která vyhlášku porušila a vydala se na shromážděni na Rathausplatz?

Kdyby ji tam někdo poznal, kdyby se kolem ni shlukli a odvlekli ji k revolučni gardě chlapi̊ s velkým červeným RG na rukávu košile, byl by konec. Zmizela by, jako za posledni měsíc zmizelo tolik jiných z jejîho okoli." 16

Vnitřně se Gerta od němectví vždy odvracela, po skončení války se však ocitá - díky svému německému jménu a nacistickému otci - v soukolí kolektivní viny a je i se svou malou dcerou Barborou vyhnána z Brna. Se štěstím přežije pochod smrti a dostává se do skupiny německých žen, které jsou v pálavské vsi Perná zařazeny na práci na statek mírumilovného sedláka Huberta Šenka. U starousedlé místní Němky Zipfelové najdou ubytování i vlídné zacházení.

Novousedlíci nemají vztah ani k dané lokalitě, ani k selskému životnímu způsobu a ocitají se postupně v zajetí komunistických idejí, v jejichž duchu združstevňují statky, odstraňují poslední zbytky ohleduplného vztahu ke krajině a původní vesnickou sounáležitost nahrazují kolektivismem řízeným stranickými funkcionáři.

Německé ženy byly trpěny jako levná pracovní síla. Protiněmecký nacionalismus nahradil v poválečném Československu dřívější soužití německých, českých i smíšených rodin, a tak bylo nutno v každé vesnici dokládat potřebnost německých pracovnic, nebot i těmto ženám hrozil odsun.

V první části románu je díky střídání vyprávěcí perspektivy zprostředkována složitá problematika viny a spravedlnosti. Gerta nijak neomlouvá svého zfanatizovaného otce a bratra, svůj osud, který jí byl určen uplatněním principu kolektivní viny, však vnímá jako pomstychtivostí motivovanou nespravedlnost. Neodbytné jsou pocity nejistoty z budoucnosti a strachu z neznáma: „Gerta by chtěla zpátky do Brna, kde je jeji domov, ona neumi žit v neznámém městě mezi cizími lidmi. Ale kam v Brně půjde? A ještě $k$ tomu s Barborou? Na koho by se mohla obrátit?"17

Série paradoxů pokračuje v poválečném Československu. Gerta se díky svému válečnému milenci Karlovi, který se stal funkcionářem KSČ, smí vrátit do odněmčeného Brna (s aluzí na nacistický termín ,judenfrei“ je třetí kapitola nadepsána „Město Deutschfrei“).

16 Tamtéž, s. 73-74.

17 Tamtéž, s. 212-213. 
Brno však již není živým a pestrým kulturním městem, Gertiným důvěrně známým domovem - s šedí nové zástavby a s novými obyvateli se mění k nepoznání.

Karel se nespokojil s oficiálním bagatelizováním divokého vyhánění Němců, začal se zajímat o skutečný počet obětí pohořelického pochodu smrti, a tak jednoho dne za nevyjasněných okolností zmizel. Bez Karlovy ochrany přežívá Gerta v neutěšených poměrech, po odchodu dcery Barbory z domu pak v úplném osamění jako společenský outsider. Všudypřítomné znevýhodňování a šikanování Gerty jako neodsunuté Němky mělo za následek slábnutí jejího češství ve prospěch nového německého sebeuvědomování - po celý dosavadní život se přitom snažila v sobě němectví potlačovat.

Bolestně prožívá Gerta své mateřství. Jen kvůli své dceři Barboře nespáchala na konci války sebevraždu, dceru vychovávala v nuzných podmínkách a nepřátelském prostředí. Musela dělat řadu kompromisů po válce i po okupaci v roce 1968, a tak se navenek krok za krokem odcizovala svému vnitřnímu já. Výsledkem bylo mj. dceřino neporozumění a později odchod z domova. $\mathrm{K}$ usmíření dcery s matkou a vzájemnému pochopení dochází až na sklonku Gertina života.

Gertina volba pasivního proplouvání poválečným Československem kontrastuje s osudy jejích německých kamarádek ze statku v Perné. Johanna dlouhá léta doufala, že se její ztracený muž vrátí, a proto vychovávala jejich děti v německém jazyce i národním duchu, což se v nenávistně protiněmeckém prostředí neobešlo bez vážných problémů. Johanna však díky svému zápasu o identitu svou i svých dětí neztratila víru a smysl života. Další z německých kamarádek, Hermína, zůstala na statku v Perné, kde se rozhodla žít jednoduchým venkovským životem v naději, že si jí noví mocipáni nevšimnou.

Postavy německých mužů jsou jednoznačně negativní. Za bližší pozornost autorce nestojí ani čeští muži (dokonce ani Gretin přítel Karel Němec), což je plně v souladu s protimužskou orientací próz Kateřiny Tučkové. Mužům je přisuzován výrazný sklon k páchání sexuálního násilí - jen Gerta je znásilněna otcem, domovníkem, továrními dělníky ve Zbrojovce, rudoarmějci, znásilnit se ji pokusí i opilý hospodář Jech.

Plasticity zobrazení autorka dosahuje při charakteristice společenských událostí, zejména válečné a poválečné atmosféry. Vedle dobových dokumentů a brněnských reálií se zaměřuje také na manipulativní mocenské praktiky a jejich dopady na psychiku obyvatel. V reakci na výhrady literární kritiky i čtenářské veřejnosti k tradičnosti a extenzitě vyprávění, neprokreslenosti postav apod. poukazuje Pavel Janoušek oprávněně na sociální rozměr románu Kateřiny Tučkové a jeho význam pro širší společenskou reflexi tabuizovaného tématu. ${ }^{18}$

Jakuba Katalpa (vlastním jménem Tereza Jandová) zaujala prvotinou Je hlína k snědku? (2006), po níž následoval román Hořké moře (2009). Román Němci (2012) se již v roce 2014 dočkal druhého vydání. Nejnovější prózou Jakuby Katalpy je román Doupě (2017). V románech Němci a Doupě opustila autorka provokativně experimentální tón, zůstala však tvůrkyní svébytných fikčních světů, jejichž funkce není v prvé řadě dokumentární.

18 JANOUŠEK, Pavel: Svědectví nejen o Gertě Schnirch aneb Takovi jsme byli. Host 25, 2009, č. 9, s. 61-62. 
Autorka, která vyrůstala a žije v Sudetech, uchopila téma německé menšiny na území bývalého Československa způsobem, který je do značné míry nový. ${ }^{19}$

Jakuba Katalpa přistupuje k vytvoření obrazu Němců v českých zemích ze zcela jiné strany, než bylo v české próze dosud běžné - aspekty politické, etické či sociálně psychologické ji zajímají pouze jako kontext, z něhož vybírá útržkovité dobové citáty známých aktérů, jejichž absurdita se vyjevuje v kontrastu s historickou realitou. Proti odleskům tzv. velké historie staví autorka malou historii každodennosti obyčejných lidí, především žen, které překvapují přímočarostí, tvrdostí, odolností a zvláštní umanutostí.

V úvodní pasáži románu vypráví mladá žena, která po smrti svého nevyzpytatelného a depresivního otce hledá v Německu jeho biologickou matku, od níž přicházely ze západního Německa dlouhá léta balíky se sladkostmi. Klára Rissmannová, pravá babička bezejmenné personální vypravěčky, se stává narativním hlasem téměř celého románu pouze v závěru je nahrazena původní vypravěčkou.

Mladá vypravěčka se po otcově smrti pustí neohroženě a důsledně do pátrání po babičce, která opustila svého syna a nikdy ho pak již nevyhledala. Svou tetou je přivedena do ústavu k ženě vysokého věku, která trpí demencí, a tak jí vnučka nemůže klást nepříjemné otázky. Autorka fabuluje životní př́iběh Kláry Rissmannové jako sled životních ztrát. Svéráznou „geografii ztrát“ rozvíjí pomocí obrazů, v nichž hraje mimořádně důležitou roli smyslové vnímání.

Stylová neutrálnost jazyka románu dává vyniknout nejednoznačnosti chování postav v kritických životních situacích. Vypravěčka se vyhýbá morálním i estetickým soudům, zálibu má naopak ve všech fyziologických projevech, o nichž se však zmiňuje bez povrchového naturalismu.

Neobvyklé je emancipované chování babičky Rissmanové, která v odlehlé vesnici, kam byla poslána jako učitelka, sama naváže sexuální vztah s rasem Weissmannem. Podobně jako její učitelský kolega Fuchs přistoupí na nabídku zástupce školního rady, aby v dopisech zasílaných na školní inspektorát donášela na ostatní učitele. Namísto objíždění vesnických škol si Klára vymýšlela pozitivní zprávy a ptala se sama sebe, zda si Fuchs také vymýšlí, když o ní podává hlášení.

V Kláře se opakovaně sváří smysl pro povinnost se zvláštní lhostejností k morálním a společenským problémům, o nichž ovšem vždy alespoň něco tuší. Klára je při společné cestě osobním vlakem s knihovníkem zámecké knihovny Melmanem konfrontována s nákladním vlakem odjíždějícím z nádraží opačným směrem: „To, že by Židé mohli být usmrcováni, ji pripadalo neuveřritelné. Neuměla si predstavit, jakým zpưsobem by něco takového mohlo probihat; když přmýšlela nad realitou těla, jeho hmotností, velikosti a silou - a navic vzala v potaz pravděpodobný odpor jeho majitele -, nezdálo se ji možné, že by kdokoliv a jakkoliv mohl vyhubit celý vlak." ${ }^{20}$ [...] i kdyby byli Židé tak nevybíravě odstraňováni, copak se to týkalo jí osobně?‘21

19 Podrobněji srov. KUČERA, Petr: Téma vykořeněni a ztrát v současné próze. Nad románem Jakuby Katalpy Němci. Slavica litteraria 22, 2019, č. 1, s. 57-67.

20 Tamtéž, s. 261.

21 Tamtéž, s. 262. 
Umírání školního inspektora Malkeho na rakovinu naopak Kláru zasáhlo, protože s touto smrtí měla osobní zkušenost: „Letmo prozkoumala léky na nočním stolku, zaregistrovala lahvičku s morfiem, injekčni stř̌kačku a tubu s präšky na spani. Ucítila, jak se ji stahuje hrdlo. Malke ji nijak zvlášt nepřirostl $k$ srdci, a presto se nedokázala ovládnout, jeho umíráni bylo tak hmatatelné, jako by se týkalo ji samé." "22

Po přeletu letadel západních spojenců nad vesnicí je Klára udivena Weissmannovým vysvětlením, že Německo válku nevyhraje. Politické a vojenské situaci nerozuměla a nezajímala se o ni. Odmítla i nabídku svého otce, který si prohru Německa připustil s předstihem, a proto zajistil pro svou rodinu únikovou cestu do Švýcarska - otci oznámila, že chce ve vesnici Rzy zůstat:

„Neumèla si predstavit, že by odešla. Už př́liš dlouho byla součástí krajiny, hor, strusky z pecí vyvážené do lesư, bilého vyklenutí nebe, úzkých pěsin protkávajicich les.

Zničila si tu plice, v Hinterbergenu nikdy tolik nekourila. Měla by ted’ opustit všsechny nedopalky, kteréšsičkou boty zahrnula jehlič́m, zapichla do květináčù na školni chodbě nebo odhodila do potoka?"23

Navzdory ironii, kterou provází každý náznak sentimentu, je patrné Klářino propojení s rodnou zemí. Ironicky vyznívá také většina aluzí na hesla nacistické propagandy, která se ocitá stále více mimo realitu konce války. Klára se naopak - i díky Fuchsovým informacím ze zahraničního rozhlasu - snaží vyrovnat s faktem německé prohry: „Klára, uviznuvši ve vesnici sevřené z obou stran horami, měla pocit, že se ocitla na konci světa. Strach se podobal vlně nesouci každého jiným směrem a nebylo možné jej sdílet, odděloval ji od Fuchse $i$ od Weissmanna." 24

Po válce přicházejí z vnitrozemí do pohraničí čeští přistěhovalci a obsazují domy po Němcích. Klára se s učitelem Fuchsem musí přestěhovat do jedné malé místnosti bývalého výměnku. Klářina nezařaditelnost se projeví i ve skutečnosti, že zmizí z evidence, a tak ji po válce na jedné straně nelze poskytovat potravinové a šatní lístky, na druhé straně ji ale také nelze odsunout.

V samém závěru románu se ke slovu opět dostává mladá personální vypravěčka, která si klade nezodpověditelné otázky o ztrátách v př́íbuzenstvu - nejvíc podle ní ztratila babička, protože jí slábnoucí pamět nedovolila sečíst životní zisky.

Obnova smyslového vnímání v konkrétní podobě jednotlivých vjemů a nezapomenutelných obrazů je největší předností románu. Nahlédnutí do mentality a osudů širšího společenství nabízí autorka jen v menší míře. Vyprávění dominuje strhující příběh ženy procházející dvacátým stoletím ve střední Evropě s udivující odolností. Tato postava se vymyká schematickému dělení na hrdiny a antihrdiny, dokonce není zcela jisté, zda je skutečnou ústřední postavou románu. V atmosfére postupujícího chladu a lhostejnosti v ponuré a opouštěné krajině se spiše zdá, že hlavním hrdinou je samo odcházení.

Postavy německých, resp. německojazyčných žen a mužů jsou v analyzovaných románech zobrazovány způsobem, který znamená v české próze odklon od etnických hodnotových souřadnic ke kritériím etickým a genderovým. Je zcela prost tendencí proti-

22 Tamtéž, s. 282.

23 Tamtéž, s. 308.

24 Tamtéž, s. 317. 
německých a antisemitských, které v různých podobách a obměnách provázely českou literaturu v devatenáctém a dvacátém století.

Záporným postavám propůjčuje negativní hodnocení nikoli etnický či sociální původ, ale fanatický příklon k nacistické nebo komunistické ideologii a zejména jejich jednání. Jednoznačným přínosem je psychologicky jemnější odstiňování pocitů a nálad ženských hrdinek, které - na rozdíl od tradiční psychologické prózy - čerpá ze systému obraznosti založeném na novém pojetí tělesnosti.

Nově vnímaná a zobrazovaná tělesná zkušenost válečných a poválečných hrůz se vpádem cizoty proměňuje, vlastní a cizí se výrazně rozděluje. Pro českou čtenářskou veřejnost je neobvyklá především skutečnost, že kategorie vlastního a cizího nejsou ustálené, ale v průběhu událostí si několikrát vyměňují svá místa, čímž silně narušují zažité stereotypy vnímání.

Autorky přenášejí akcent z dřívějšího pozorování a vnímání na prožívání událostí, a tak vyvazují procesy recepce z dosud převažující oblasti racionální do sféry citové. Tradiční mužská rezervovanost v projevování citů se však v analyzovaných románech neprezentuje jako záležitost jevové stránky, ale jako deficit (zejména u Kateřiny Tučkové se násilnické mužské postavy blíží monstrům s amputovanými emocemi). Axiologický schematismus, který byl dříve založen etnicky či ideologicky, je tak více či méně nahrazován schematismem motivovaným genderově.

Rozporuplné přijetí románů českých autorek tematizujících válečné a poválečné osudy českých a moravských Němců (a německojazyčných Židů) jak literární kritikou, tak i čtenářskou veřejností na sociálních sítích je paradoxně dobrým znamením, nebot signalizuje společenskou potřebnost hlubšího uměleckého ponoru do problematiky etnických konfliktů moderní doby.

\section{Prameny}

DENEMARKOVÁ, Radka: Penize od Hitlera. Brno: Host, 2006. 248 s.

KATALPA, Jakuba: Němci. Brno: Host, 2012. 424 s.

TUČKOVÁ, Kateřina: Vyhnání Gerty Schnirch. Brno: Host, 2009. 416 s.

\section{Literatura}

DYSERINCK, Hugo: Zum Problem der ,images“ und ,mirages' und ihrer Untersuchung im Rahmen der Vergleichenden Literaturwissenschaft. Arcadia 1, 1966, s. 107-120.

JANOUŠEK, Pavel: Svědectví nejen o Gertě Schnirch aneb Takoví jsme byli. Host 25, 2009, č. 9, s. 61-62. KUČERA, Petr: Téma vykořeněni a ztrát v současné próze. Nad románem Jakuby Katalpy Němci. Slavica litteraria 22, 2019, č. 1, s. 57-67.

MAIDL, Václav: Obraz německy mluvicich postav a německého prostředi v české literatuře 19. a 20. století. In: KřEN, Jan - BROKLOVÁ, Eva (eds.): Obraz Němců, Rakouska a Německa v české společnosti 19. a 20. století. Praha: Karolinum, 1998, s. 281-302. 
NANCY, Jean-Luc: Vetřelec. Filosofický časopis 59, 2011, č. 1, s. 47-59.

PEKÁREK, Martin: Jednou se stanu spisovatelkou. Protimluv 5, 2006, č. 3, s. 35-36.

RATAJ, Jan: Obraz Němce a Německa v protektorátni společnosti a československém odboji. In: KŘEN, Jan - BROKLOVÁ, Eva (eds.): Obraz Němcri, Rakouska a Německa v české společnosti 19. a 20. století. Praha: Karolinum, 1998, s. 207-235.

SCHALLNER, Dieter: Obraz Němců a Německa v letech 1945 až 1947. Vznik soudobého českého stereotypu Němce a Německa. In: KŘEN, Jan - BROKLOVÁ, Eva (eds.): Obraz Němců, Rakouska a Německa v české společnosti 19. a 20. století. Praha: Karolinum, 1998, s. 236-252.

SEIBT, Ferdinand: Německo a Češi. Dějiny jednoho sousedstvi uprostřed Evropy. Přel. Petr Dvořáček. Praha: Academia, 1996.

STANĚK, Tomáš: Odsun Němců z Československa 1945-1947. Praha: Academia, 1991.

TRÁVNÍČEK, Jiří: V této knize se toho sešlo nějak moc. Host 21, 2005, č. 7, s. 11-12.

VAJCHR, Marek: Dobrosrdečný mazák a divý borec. Revolver revue, 2007, č. 68, s. 225-230.

VÁLEK, Miroslav: Domov sú ruky, na ktorých smieš plakat. In: VÁLEK, Miroslav: Básnické dielo. Bratislava: Kalligram - Ústav slovenskej literatúry SAV, 2005, s. 96-97.

WELLEK, René: The Crisis of Comparative Literature. In: Proceedings of the second congress of the International Comparative Literature Association, Chapel Hill 1958. Chapel Hill, 1959, s. $149-159$.

doc. Dr. Petr Kučera, Ph.D.

Katedra germanistiky a slavistiky

Filozofická fakulta, Západočeská univerzita v Plzni

Riegrova 11, 30614 Plzeň, Česká republika

pekucera@kgs.zcu.cz

Toto dílo Ize užít v souladu s licenčními podmínkami Creative Commons BY-SA 4.0 International (https://creativecommons.org/licenses/by-sa/4.0/legalcode). Uvedené se nevztahuje na díla či prvky (např. obrazovou či fotografickou dokumentaci), které jsou v díle užity na základě smluvní licence nebo výjimky či omezení př́slušných práv. 